\title{
LEFT AND RIGHT IN ROMAN COINS OF \\ THE FOURTH AND FIFTH CENTURIES A.D. \\ By \\ FERNANDO LÓPEZ SÁNCHEZ
}

\section{Why Left and Right? ${ }^{1}$}

The great weakness of the Roman political system was always the lack of any constitutional mechanism to regulate the transfer of power. ${ }^{2}$ Because of this, any regime with ambitions to endure had to base its claims on its efficiency and pragmatism. This is why action alone was not enough; the art of persuasion was at least as important.

In Roman iconography, left and right are not positions left to chance. If the Latin mind conceived of movement as being from left to right, then it is only logical to extrapolate that this will be mirrored in the plastic arts. It clearly occurs in writing, but also in icon-based narration. A right-facing position on Roman coins signifies initiative and constancy in the achievement of an objective, while a left-facing one denotes a pause, either temporary or permanent, in such an undertaking. This simple dichotomy tends to obviate full-frontal positions, the static nature of which makes them not suited to the language of narration. ${ }^{3}$

The patterns that govern the duality of right/initiative and left/resolution are mainly of a military nature. The bellum/pax division so beloved by modern-day scholars is not supported by the more Roman domi' militiae. ${ }^{4}$ Because of this, the dialectic between both concepts is one of continuity and not one of opposition, and the majority of monetary iconography is based on this fundamental premise.

\footnotetext{
${ }^{1}$ Translation from Spanish by Mark Temple, Editor ELT Dictionaries, Oxford University Press.

2 J.A.S.Evans, 'Byzantine Kingship: the claim of dynastic right', The Ancient World 18, 1-2 (1988), 53: "If we compare the mini-dynasties of Imperial Rome with the royal families of medieval Europe such as the Capets and the Angevins, it must strike us that Rome had extraordinarly bad luck ... that was a product of Rome's unstable society ... At any rate, the would-be dynasties failed".

${ }^{3}$ L. Kurhe, Coins, Bodies, Games and Gold: The Politics of Meaning in Archaic Greece (Princeton 1999), 23: "Because coinage is a polyvalent symbol within a complex symbolic system, the struggle I endeavour to reconstruct is a struggle fought over and in representation".

${ }^{4}$ G. Woolf, G, 'Roman peace', in J. Rich \& G. Shipley, eds., War and society in the Roman world, (Londres-NewYork 1993), 173: "Central to understanding imperial uses of the notion of peace is ... these turned not so much on an opposition between pax and bellum as on an opposition between two moral and religious spheres, domi and militae...". J. Rüpke, Domi militae. Die religiöse Konstruktion des Krieges in Rom, Stuttgart 1990.
} 


\section{The Soldatenkaisertum in the fourth century}

The period beginning with the crisis of the third century, when the emperor was obliged by external military pressures to pay more attention to army matters, is vital to understand the left-right dichotomy. However, it is very hard to place all the complex and numerous series of the third century in clear chronological order.

In the fourth century, on the other hand, it is possible for us to be more exact. The iconographic sequences are more structured and we can establish a general behavioural model. Owing to the short duration of the episode and the clarity of its coin series, the ideal starting point for such a reconstruction is the "usurpation" of Vetranio in 350.

After Magnentius took power in Gaul on the 18th of January 350, a certain Vetranio stirred up a revolt in Sirmium-Mursa on the first of March of that same year. ${ }^{6}$ The most orthodox, though not the only, viewpoint on this $^{7}$ was that Vetranio wanted to save Illyricum on behalf of Constantius II, as "an invasion by Magnentius from Italy into Illyricum became a real danger to Constantius". 8

Vetranio did not, however, keep the Illyrian army ready for the triumphant arrival of the legitimate emperor Constantius II $^{9}$ but stirred up a revolt in the face of the very real possibility of an invasion of the Balkans from the west. It was not because of any divided loyalties between Magnentius and Constantius II, but in order to show the region's independence from foreign powers that the Illyrian army rose up under Vetranio, Magister Peditum of Pannonia. For ten months Vetranio had a large number of coins minted in his name, showing himseld as an autonomous emperor with the intention of remaining in power for a long time. ${ }^{10}$

\footnotetext{
${ }^{5}$ O. Seeck, Regesten der Kaiser und Päpste (Stuttgart 1919), 197.

${ }^{6}$ Seeck 1919, op. cit (n. 5), 196.

${ }^{7}$ B. Bleckmann, 'Constantina, Vetranio und Gallus Caesar', Chiron 24 (1994), 44, 54, gave a radically different interpretation of Vetranio's revolt, considering him not as a puppet but as a fullyfledged emperor. See also J. F. Drinkwater, 'The revolt and ethnic origin of the usurper Magnentius (350-353) and the rebellion of Vetranio (350)', Chiron (2000), $131 \mathrm{ff}$.

${ }^{8}$ Šašel, J., 'The Struggle between Magnentius and Constantius II for Italy and Illyricum', Ziva Antika 21 (1971), 207; O. Seeck, Geschichte des Untergangs der antiken Welt IV (Sttutgart 1922), 92 ff; A. Demandt, Die Spätantike, Römische Geschichte von Diocletian bis Justinian, 284-565 n. Chr. (Munich 1989), 83.

${ }^{9}$ Drinkwater 2000, op. cit. (n. 21), 149: "The proclamation of Vetranio is therefore significant because it must reflect the depth of feeling in the Balkans..., and so suggests the implausibility of any early involvement by Constantina: Vetranio and his senior advisers will have acted by and for themselves".

${ }^{10}$ Vot./VMult./X on the reverse, RIC 8, Sis. 261-R4.
} 
The depiction of Vetranio on his coins show his features in accordance with the standard tetrarchic model: ${ }^{11}$ a large head, strong jawline, well-shaped beard, short hair, a thick-set neck, an air of responsibility and a smile of facilitas (Plates I, fig. 1-3). All this denotes an official who may be uncultured but who is accessible to his subordinates, the image of a man who has risen through the ranks. All this is a great contrast to the Apollinian portraits of the Constantinians.

Vetranio is shown being crowned by Victoria on the reverses of his most representative solidi (Pl. I, fig. 1), with the whole scene facing left. Most of these series were minted in Siscia or Sirmium, or sometimes in Thessalonica, with Magnentius' invasion looming.

The Salvator Rei Publicae inscription on Vetranio's solidi expresses the worries of the Illyrian army in a moment of crisis. It is not a question of Vertranio's usurping power, but simply of the highest powers being conferred on a general by his army in a time of political instability.

The left-facing posture signifies the plenitude and ratification of his power. While Vetranio's solidi are revealing, the same is true of his centenionales. The Concordia Militum series where Vetranio holds two labara (Pl. I, fig. 2) denotes the concord between the two opposing armies, the Gallic and the Danubian, and points out to us the man chosen by providence to forge this agreement. Vetranio is in a frontal position, midway between the two standards and facing left; according to a strict iconographical code, he is represented as the one destined to solve the military crisis (see the star on his head).

Nevertheless, the most common type of centenionales follows the militaristic model of Salvator Rei Publicae. The Hoc Signo Victor Eris coin series spread the image of Vetranio as a fully-fledged commander (Pl. I, fig. 3 ). It is all but certain that the event evoked here is the battle of Milvian Bridge on the 28th of October 312 , and that the echo of this key Constantinian victory reached Naissus, the birthplace of Constantinism in the Danubian region, and so reminded the governing prince of the need to have the Illyrian army on his side. ${ }^{12}$ The Sirmian military did not want a Gallic army in the Balkans and rejected the foreigner Magnentius.

\footnotetext{
${ }^{11}$ Drinkwater 2000, op. cit (n. 7), 137: "I would indeed suggest that hopes of reviving and exploiting tetrarchic principles were central to the thinking of those involved in what may be termed the 'Magnentian experiment' ", and on p. 138: "there may even have been some idea of projecting him as the new Diocletian".

${ }^{12}$ A. Baldini, 'Claudio Gotico e Constantine in Aurelio Vittore ed Epitome de Caesaribus', in G. Bonamente \& F. Fusco, eds., Costantino il Grande: Dall'Antichità all'Umanesimo. Colloquio sul Cristanesimo nel mondo antico, Macerata 18-20 Dicembre 1990 (Macerata 1991), $73 \mathrm{ff}$.
} 
The Hoc Signo Victor Eris centenionales, with their thoroughly military character, were minted in large quantities in Siscia and in Sirmium between March 350 and March 351, and constitute a resistance to Western meddling in the Balkans, and an appeal to the values of Naissus, the regionalist values of self-defence.

Constantius II did not exercise full control over Illyricum until 350 , and even then he did not hurry to occupy a region that had never fully bowed to his commands. This explains why he was so slow to go to meet Vetranio, ten full months after the insurrection, and in turn why the meeting between the two in Serdica, ${ }^{13}$ Illyricum's gateway to the East, was more like a customs operation than a friendly reception.

It was only after Constantius had gone to the effort of haranguing the soldiers in Naissus, treating them as commilitones (fellow soldiers) ${ }^{14}$ and not as a Porphyrogenitus emperor, that the army rallied to his call and Vetranio abdicated as a gesture of approval. The soldiers of another commander scrutinised Constantius carefully, rather than blindly following him.

To reach the consensus that made the abdication of Vetranio possible, Constantius had to make concessions to the Danubian military high command, and he did this by the immediate nomination as governor (15th of March 351), in the military capital Sirmium rather than in Siscia, of a Caesar, Constantius Gallus. It was only after this that Constantius II and Constantius Gallus could mint coins in the Balkans as military commanders at a critical historical moment (Pl. I, fig. 4, 5, 6).

\section{A military cursus honorum}

Were Vetranio's approach to coins unique, we would have no more than the story of a military coup in the year 350. But, in the Balkans, both Constantius Gallus and Constantius II chose exactly the same iconography as Vetranio. Were they too subscribing to a tradition of subordination to the power of the army?

The established and much-loved assumption of traditional historiographers is that, with Constantine's progressive taking of power between 312 and 324, a new world view was born. After the crises of the

\footnotetext{
${ }^{13}$ Zonaras 13.7 .

${ }^{14}$ Proximity to the army in Ammianus Marcellinus 14.10.13: “... commilitones mei fidissimi, accipite aequis auribus quae succintius explicabo." Constantius II communicated far more with his army than has been supposed, R.C. Blockley, 'Constantius II and his generals', Latomus 168 (1980), $467 \mathrm{ff}$.
} 
third century, Constantine had managed to heal the wounds, ${ }^{15}$ and the violent, pagan, militaristic ethos of before was replaced by urbanity, Christianity, and bureaucracy. However, coin series keep showing us, to the point of tedium, that most of the worries of the empire were centred on the military situation. The emperors of the third century had all come to power through regionalism and militarism, ${ }^{16}$ and this tendency did not only remain the same in the fourth century, but even appears to have increased. The example of Constantius' rise to become emperor of the entire Roman world is proof of this, ${ }^{17}$ coming about as it did through pure chance, and in particular the existence of Magnentius' military threat in the Balkans.

Throughout the fourth century the de facto division between East and West which we saw in the third century with Postumus and Gallienus remained strong. No emperor was able to maintain long-term control over both the Gauls and Illyricum, the two most important regions of the empire in military terms. As this situation was the result of mistrust between the two regions, the leader endorsed by the army was the one who provided the strongest guarantees for the continuing autonomy of the region; the army was not at odds with civil society, but was indeed the only body in that society capable of acting in a coordinated manner. All the emperors of the fourth century without exception owed their power to the patronage of one or more regional armies. ${ }^{18}$

When Vetranio is sworn in as supreme commander, and therefore as emperor, he chooses the highest of all iconographies, as if it were a military decoration (Pl. I, fig. 1). The inscription selected is that of Salvator Rei Publicae, because he is the spokesman of an army which sees itself as mediator and decisive player in the crisis brought on by the unstable Gauls. Constantius and Constans, on the other hand, prefer the inscription Hoc Signo Victor Eris (PI. I, fig. 4, 6), because, thanks to their ties with Constantine, they can present themselves as the champions of the Illyrian army.

When Constans, the young son of Constantine, was promoted to the purple of military command in the year 337 , a similar image of confirmation

\footnotetext{
${ }^{15}$ J. Harries, 'Towards a new Constantine', Ancient Society, Resources for Teachers 15 (1985), $71 \mathrm{ff}$; J. Gaudemet, 'Constantin, restaurateur de l'ordre', in Studi in onore di S. Solazzi (Naples 1948), 652 ff.

${ }^{16}$ C. E. Sickle, 'Particularism in the Roman Empire during the Military Anarchy', Ancient Journal of Philology 51 (1930), $343 \mathrm{ff}$.

${ }^{17}$ F. López Sánchez, 'La tutelle de l'armée illyrienne sur la dynastie constantinienne', Cahiers Numismatiques 151 (2002), $39 \mathrm{ff}$.

${ }^{18}$ F. Heim, 'Vox exercitus, vox Dei. La désignation de l'empereur charismatique au IVe siècle' Révue des Études Latines 68 (1990), $160 \mathrm{ff}$.
} 
in power appears in his first Siscian solidi, ${ }^{19}$ the advance party of westwardheading Sirmium ${ }^{20}$ (Pl. I, fig. 7). Max. Avg. makes it clear that, despite his youth, Constans enjoys a status higher than any of his brothers; being in charge of the fundamental Balkan region was enough for his army to accord him that position. Constantius II is also shown in Siscia in an honourable left-facing position (Pl. I, fig. 8), unlike Constantine II, the Western emperor.

The image of the emperor as military commander is facing left (Pl. I, fig. 7,8), and this is due to the fact that the capability of both is recognised by the Illyrian army. ${ }^{21}$ The image is as emphatic as in $350-1$, because the army has accepted them as worthy to lead.

In the year 340 we have a second confirmation of Constans' power. As Magnentius was to do ten years later, Constantine II invaded Italy, with the intention of coming to the rescue of the weakened Constantius II with troops prepared for the imminent Persian campaign. ${ }^{22}$ The idea of his crossing the Balkans on foot was greeted with extreme hostility by the Illyrian military high command, who decided to block Constantine's passage on the border of their territory, at Aquileia, where, in 340, the Gallic army was defeated and Constantine II killed. ${ }^{23}$ In this battle Constans won not only the whole of the West, but also the full respect of his own army.

Before the decisive combat with Constantine II, Constans gave donativa among his men. Few of these coins have been found, but one double solidus clearly from this period shows the emperor facing left, crowned by Victoria, with the inscription Gaudium Populi Romani (PI. I, fig. 9). This is the typical image of the army grouped around its commander, and, more than that, the image of an army which recognises him as in full possession of power (this is 340 , and not 337), which explains the crowning by Victoria. This image corresponds to a moment just before the battle of Aquileia, and not just after, nor at any other time between 337 and 340. As in all codified language, it expresses more an attitude of mind - here the Illyrian

\footnotetext{
${ }^{19}$ P. Bruun, 'Constans Maximus Augustus', in H. Huvelin, M. Christol \& S. Gautier, eds, Mélanges de numismatique offerts à Pierre Bastien à l'occasion de son 75e anniversaire (Wetteren 1987), 195: "Without any doubt Siscia was Constans' chief mint, and particularly in the years 337-340".

${ }^{20}$ The Sirmian military high command, created by the emperor Philip the Arabian (244-249), functioned as one of the most powerful of all military institutions. From its creation, a small number of high-ranking officials made or destroyed emperors, often against their own will (as in the case of Traianus Decius, Zosimus 1.21.2-3; Jordanes Getica 16.90) with the aim of resolving crises. See G. Brizzi, 'Soldatenkaiser, Illyricani ed altri problemi', Rivista Storica dell'Antichità 8 (1978), 94, 97.

${ }^{21}$ López Sánchez 2002, op.cit (n. 17), 43.

${ }^{22}$ Itinerarium Alexandri 1.4.

${ }^{23}$ December of 340; Hieronymus, Chronica 235'; Chronica minora 1.236; Epitome 41.21; Socrates, Historia Ecclesiastica 2.5; Zonaras 13.5.6.
} 
army's view of Constans - than the specific reality of military victory. This is an important distinction, as in this case the left-facing orientation symbolises not a victory already achieved, but a desire to achieve that victory.

\section{Constantine's subordination to the army}

After the battle of Milvian Bridge in 312, it was the conquest of the Balkans, which made Constantine the most powerful man in the empire.

His campaigns against Licinius between 316 and 324 convinced the Illyrian military high command of his prowess as commander-in-chief. ${ }^{24}$ Licinius was in fact the spokesman of the Illyrian army, as Vetranio was in $350,{ }^{25}$ and they shared the same tetrarchic traits and the same subordination to military power. Constantine too did not stray from this tetrarchic tradition. ${ }^{26}$ His genius, though, was to present himself with the salvational character of a Claudius II or an Aurelian, ${ }^{27}$ and not with the air of a Diocletian. While the language was different, their objectives were the same, and both men always tried to appear the representatives, and not the governors, of their army.

Constantine's two wars against Licinius, divided by the truce of 317 , led to the use of an iconographic language more aggressive than that used previously in Trier. Going back to the third century tradition and leaving the tetrarchic collective one, he revived the militaristic meaning of the colour purple. In $321^{28}$ he was depicted with globe and a spear at the ready on his left, crowned by Sol and with the inscription Invicto Soli Comiti, claiming his rightful place in the Balkans (Pl. I, fig. 10). In $323,{ }^{29}$ when Constantine was Senior Augustus, the image of the emperor crowned again by Sol is shown in Sirmium in a left-facing position (Pl. I, fig. 11).

In 317 Licinius brought out a large series in bronze to commemorate the pact with Constantine. ${ }^{30}$ This series shows heavy-set features and large heads,

\footnotetext{
${ }^{24}$ Between 316 and 323 Constantine lived predominantly in Sirmium and Serdica, Seeck 1919, op. cit (n. 5), 165-172, describing Serdica at this time as "my Rome". See F. Millar, The emperor in the Roman World (31 BC-AD 337) (Oxford 1977), $12 \mathrm{ff}$.

${ }^{25}$ P. Bruun, 'The Negotiations of the Conference of Carnuntum', Numismatica e Antichità Classiche 8 (1979), 255 ff.; R. Andreotti, 'L'imperatore Licinio nella tradizione storiografica latina', in Hommages à L. Herrmann, Collection Latomus 44 (Bruxelles 1960), $105 \mathrm{ff}$.

${ }^{26}$ R.R.R. Smith, 'The public image of Licinius I: Portrait and imperial ideology in the early fourth century', Journal of Roman Studies (1997), $170 \mathrm{ff}$.

${ }^{27}$ T. Preger, 'Konstantinos Helios', Hermes 36 (1901), $457 \mathrm{ff}$.

${ }^{28}$ Same position in Sirmium in 316, before the truce with Licinius.

${ }^{29}$ Same position in Sirmium in 317, after the truce with Licinius.

${ }^{30}$ H. Mattingly, 'Jovius and Herculius', Harvard Theology Review 45 (1952), $131 \mathrm{ff}$.
} 
short hair and a serious demeanour ( $\mathrm{Pl}$. I, fig. 12). The orientation is invariably to the left, owing to the decisive character of the new mutual agreement.

The pact of 317 , in which Licinius II, the son of Licinius, and Constantine II and Crispus, sons of Constantine, were appointed Caesars, appears to have been imposed on Licinius by Constantine. ${ }^{31}$ Heredity certainly did not seem to be typical of the concerns of a tetrarchic commander. Constantine did, however, submit to the collective principle so vital to the Roman military mentality. In 324, after removing both Liciniuses from the scene, he minted numerous series in the same mode as Licinius in 317 , albeit with the introduction of certain important differences.

The castra series which Constantine minted in bronze between 324 and 330 were in honour of Constantine II, Constantius II (Pl. I, fig. 14) and Crispus, as well as of himself (Pl. I, fig. 13). The features of all of these on the obverses are nevertheless Apollinian and not herculean or tetrarchic, ${ }^{32}$ and there is a star crowning the gate of the castrum in all of these series, something not found in Licinius' 317 coins (Pl. I, fig. 12) (same charismatic star with Vetranio in 350 , see Pl. I, fig. 13). While these series were coined in various mints, Arles was the most important. ${ }^{33}$

With this coinage, Constantine wanted, after his victory in 324 , to combine the concepts of collectiveness and dynasty, and this is why he brought out significant series in bronze exalting his family and Arles (Pl. I, fig. 14), his symbolic capital in the West. ${ }^{34}$ At the same time he shows, in this and in other pictures (Gloria Exercitus, Pl. I, fig. 15), the greatest respect for the army, to which he presents his full lineage.

Out of all those honoured by the military-dynastic coinings, Crispus is the one with the highest percentage of left-facing positions. This preference is common in his coin series and differs from those of his brothers. The choice of a naked torso and a Macedonian shield assimilates him into the Macedonian royal family (Pl. I, fig. 16), to which Constantine had wanted to become

\footnotetext{
${ }^{31}$ A. Chastagnol, 'Les quinquennalia des trois Césars (Crispus, Licinius II, Constantin II) en 321', in J. Straub, Romanitas-Christianitas. Untersuchungen zur Geschichte und Literatur der römischen Kaiserzeit (Berlin-New York 1982), 367 ff.; A. Chastagnol, 'Les decennalia de Licinius', Recueil d'hommages à Henri Stern (Paris 1983), $97 \mathrm{ff}$.

32 S. E. Knudsen, The portraits of Constantine the Great:Ttypes and Chronology, A.D. 306-337, (Ph.D Santa Bárbara 1988, An Arbor University Microfilms International 1991).

${ }^{33} \mathrm{~T}$. Bayet, 'L'iconologie des enceintes et des portes de camp sur les monnaies du Bas-Empire romain', Révue Belge de Numismatique 150 (1994), $5 \mathrm{ff}$.

${ }^{34}$ S. T. Loseby, 'Arles in Antiquity', in C. Neil \& S.T. Loseby, Towns in Transition: Urban Evolution in Late Aantiquity and theEarly Middle Ages (Aldershot 1996), 50; P. A. Février, 'Arles au IVe et Ve siècles. Ville impériale et capitale régionale', in $X X V$ Corso di Cultura sull'Arte Ravennate e Bizantina (Ravenna 1978), $127 \mathrm{ff}$.
} 
connected ever since the foundation of Constantinople as the new Troy. This typology is never adopted by either Constantius or Constantine II and highlights Crispus as the heir to the throne. ${ }^{35}$

\section{Dynasty and military advancement.}

Military promotion is the highest form of palace accolade. In contrast to what is normally thought, there is a variety of evidence to suggest that Constantius II, for example, did consider Gallus and Julian as fit to wear the purple, ${ }^{36}$ and that is why he decided to promote his Caesars through the ranks of the military. ${ }^{37}$

Julian was only appointed Caesar in Milan after intensive military training in Gaul (A.D. 354). Constantius II himself appears in 355 (mint of Arles) on the same type of miliarensis, with standards ready for action (Pl. I, fig. 17), as Julian does (Pl. I, fig. 18); this is a gesture of solidarity with his nephew, promoted to the forefront of the army of the Gauls. As miliarenses were coins imbued with the iconography of founding and new beginnings, their minting by Constantius in 355 can only be understood in relation to the presentation of Caesar Julian before the army.

The majority of the miliarenses follow a very clear left-right orientation. Constantius Gallus, for one, had been depicted facing left on the reverses since the year 351 (Pl. I, fig. 19). He had always taken up a strong position of his own, and it was precisely this independence from Constantius that irritated the palace. He was promptly relieved of his command and executed.

Julian's career follows all the normal parameters of insertion into the imperial military structure. On the death of Constantius II and given the lack of any suitable rivals, Sirmium and Antiochia (PI. I, fig. 20) decided to recognise his full sovereignty with a left-facing position (nine years later than Gallus!). His likeness also becomes more solidly-built and tetrarchic.

Julian's career was that of a man in a continuous state of selfjustification. The army of the Gauls chose him as an Augustus so that he might

\footnotetext{
${ }^{35}$ F. López Sánchez, 'Procope et le bouclier macédonien (365-366 après J.-C.), Cahiers Numismatique 156 (2003) 66ff; H.A. Pohlsander, 'Crispus: Brilliant Career and Tragic End', Historia 33, 1 (1984), 79 ff.; P. Guthrie, 'The execution of Crispus', Phoenix 20 (1966), 235 ff. ; D. Woods, 'On the Death of the Empress Fausta', Greece \& Rome 45 (1998), $70 \mathrm{ff}$.

${ }^{36} \mathrm{~N}$. Henck, 'From Macellum to Milan : The Movements of Julian the Apostate from A.D. 348 to 355', Kodai 10 (1999/2000), 111 ff.; Idem, Images of Constantius II: 'ho philantropos basileus' and imperial propaganda in the mid-fourth century A.D. (Oxford 1998), unpublished dissertation, under the direction of J. F. Drinkwater. Henck rightly points out the problems of the reign of Constantius II.

${ }^{37} \mathrm{~J}$. Béranger, 'Julian l'Apostat et l'hérédité du pouvoir impérial', in Bonner Historia Augusta Colloquium 1970 (Bonn 1972), 75 ff.
} 
provide an effective defence for the region, ${ }^{38}$ and it is at this time (360, mint of Arles) that we see the appearance of the marching emperor, with a trophy over his shoulder and dragging a barbarian by his hair (Pl. I, fig. 21). Reusing an inscription commonly used by Constantine and Constans - Virtus Exerc(itum) Gall(orum) - Julian shows himself to be a dynamic emperor. In Sirmium (361), after the discharge of most of the Gallic troops, ${ }^{39}$ the inscription becomes more general (Virtus Exercitus Romanorum), but the position is the same (Pl. I, fig. 22). In order to become fully accepted by a still distrustful Illyrian army, Julian then decided to attack on the Persian front. ${ }^{40}$

The Persian campaign did not, however, ever meet the approval of the Illyrian military high command, worried about the removal of the garrison from the Balkans. Whether Julian was assassinated or not is of secondary importance, however, compared to the obvious hostility of the Palatine Guard, which was almost entirely composed of Illyrians. It was of course Procopius, the least Illyrian of the candidates, who was rejected unconditionally as Julian's successor, which in turn led to the short but very intense civil war described by Ammianus. ${ }^{41}$

Despite the fact that the Illyrian army was not in favour of it, the Persian campaign was seen as a victory once brought to a successful conclusion; both the invasion and the withdrawal were living proof of the power of Rome. ${ }^{42}$ On minting coins, Jovian paid due credit to both the region for which he fought - the East - and to the power behind the campaign Illyricum. ${ }^{43}$ In Sirmium, however, and not Antioch, a captive is shown humiliated by the emperor, who looks leftwards towards him (Pl. I, fig. 23) ${ }^{44}$

\footnotetext{
${ }^{38}$ According to Ammianus' version, Julian did not want his troops in Paris to revolt (20.4.11), and the revolt was a spontaneous event (20.4.14) that ended when Caesar assentire coactus est (20.4.17); there is a similar vision of the events in Libanius Oratio 18. 96-99. Theophanes recalls how Julian, buoyed by his successes against the Barbarians, seized power and crowned himself with a diadem, Chronica 71 b-c.

${ }^{39}$ J. Szidat, 'Zur Ankunft Julians in Sirmium 361 n. Chr auf seinem Zug gegen Constantius II', Historia 24 (1975), $375 \mathrm{ff}$.

${ }^{40}$ M. Gawlikowski, 'L'empereur Julien sur les bords de l'Euphrate', Des Sumériens aux Romains d'Orient. La perception géographique du monde, Antiquités Sémitiques II (Paris 1997), 154: "Le terrain de confrontation entre Rome et la Perse était désormais dans le nord, du côté de Nisibe. En choisissant la route de l'Euphrate, Julien s'est de nouveau montré un homme du passé".

${ }^{41}$ López Sanchéz, op.cit. (n.35), 57ff; J.F. Matthews, The Roman empire of Ammianus (London 1989), 192; B. Bousquet, 'Le raz de marée du 21 juillet 365: du cataclysme local à la catastrophe cosmique', Mélanges de l'École Française de Rome, Antiquités, 96 (1984), $423 \mathrm{ff}$.

${ }^{42}$ Ammianus Marcellinus 25.7.5; Themistius 5.66; Festus, Breviarium 29.

${ }^{43}$ G. Wirth, 'Jovian. Kaiser und Karikatur', Jahrbuch für Antike und Christentum 11 (1984), 353 ff. rehabilitates the political value of Jovian as the successor and the continuation of Julian's policies.

${ }^{44}$ K. Ehling, 'Des Ausgang des Persefeldzuges in der Münzpropaganda des Jovian', Klio 78 (1996), 186.
} 
This position is fundamentally the same as that of Constantius in 337 (PI. I, fig. 8), but with greater emphasis on the crushing nature of the victory.

The fact that the fourth century must be seen as a continuation of the tradition of "Soldatenkaisertum" is clear from some of the most representative series of the period. ${ }^{45}$ The famous and extremely common bronze series of 348 minted by Constans and Constantius contain a dialogue between obverse and reverse, representing on one side the tasks already completed and on the other those yet to be done by the emperor. ${ }^{46}$

The barbarian is energetically vanquished in the "fallen horseman" type, and on the obverse the emperor naturally faces right (Pl. I, fig. 24). Rome is conquering its greatest enemy, the Sassanid Persians, and once they are defeated and in chains - in another series of 348 - the obverse is facing left with globe in hand, with the reverse also to the left (Pl. I, fig. 25).

During the diarchy of the joint government of Valentinian and Valens, for example, the bust of Valentinian in full armour, is complemented on the obverse with an image of the transfer of power to Gratian by the Senior Augustus $^{47}$ in Trier in 367 (Pl. I, fig. 26). It is clear why there are no similar solidi relating to Valens. A fully-armed, left-facing bust therefore denotes a hereditary promotion through the military ranks (see also Pl. I, fig.. 14, 16).

In order to rein in over-powerful generals, Pulcheria began to develop the model of the fifth century "par excellence" in $421 .{ }^{48}$ With the background of the Persian war and the desire for influence over the West, Constantinople became the guiding light of the Roman world. Wanting to reaffirm the power of the threatened Theodosian dynasty, Pulcheria closed the door on any attempts to gain power on the part of the military. ${ }^{49} \mathrm{He}$ imposed semi-monastic mores in Constantinople and extolled the cult of

\footnotetext{
${ }^{45} \mathrm{~F}$. Altheim, Die soldatenkaiser (Frankfurt am Main 1938); E. Frézouls, 'L'accession au pouvoir des empereurs illyriens', in E. Frézouls \& H. Jouffroy, eds., Les empereus illyriens, Actes du colloque de Strasbourg, 11-13 octobre 1990 (Strasbourg 1998), 5 ff.; R. Syme, 'Danubian and Balkan emperors' Historia 22 (1973) = Roman Papers III (1984), $892=310$ : "The great military emperors who came out of Illyricum are often termed 'Illyrian'; and some may even be assigned 'Illyrian blood'. The term is vicious and misleading. It is also too vague and too narrow".

${ }^{46}$ W. Portmann., 'Die politische Krise zwischen den Kaisern Constantius II und Constans', Historia 48,3 (1999), 301 ff.; J-P. Callu, 'La dyarchide constantinide (340-350): les signes d'évolution', in Institutions, Societé et Vie politique dans l'empire romain au Ive siècle ap. J-C-, Collection de l'École Française de Rome 159 (1992), $40 \mathrm{ff}$.

${ }^{47}$ M. Fortina, L'imperatore Graziano (Torino 1953 ).

${ }^{48}$ K.G. Holum, 'Pulcheria's Crusade A.D. 421-22 and the Ideology of Imperial Victory', Greek, Roman and Byzantine Studies 18 (1977), 155.

${ }^{49}$ K. G. Holum, 'Family life in the Theodosian House', Kleronomia 6 (1976), $280 \mathrm{ff}$.
} 
virginity. ${ }^{50}$ The image of Victoria holding up a large cross expresses these totalitarian ideas, which are reinforced by the decisive right-facing orientation (Pl. I, fig. 27).

Every Western emperor affirmed his affiliation to East or West through the model chosen for the reverses of his coins. Although it is not so clear an expression as the image of Victoria, the emperor crushing underfoot the human-headed serpent was the Constantinopolitan model in its Ravenna version. In contrast to the aggressive, self-justifying posture of John, Avitus (Pl. I, fig. 28) or Glycerius, always facing right in the style of the Theodosians, ${ }^{51}$ Valentinian III (Pl. I, fig. 29), Leo and Libius Severus adopt the decisive model of the East, satisfied with its achievements. The Western supporters of the Anicii saw their aspirations to a militarised basileia frustrated, ${ }^{52}$ and with their defeat the Western emperors lost their very "raison d'être". With them disappeared the notion of true, working Romanitas, the idea that a ruler was only a ruler in so far as he was able to resolve problems.

The left-right dialectic, as we have seen, was therefore the instrument most favoured by the authorities in the iconography of coins, a rich source of information on the narration of legitimacy in the Roman empire.

Zaragoza, September 2002.

\footnotetext{
${ }^{50}$ K.G. Holum, Theodosian empresses. Women and Imperial Dominion in Late Antiquity, (BerkeleyLos Angeles-London 1982), 227: "by showing reverence here to the Theotokos, they secures the power of their basileia".

${ }^{31}$ F. López Sánchez, 'Innovation et prestige dans le monnayage d'Avitus', Cahiers Numismatiques 149 (Paris 2001), $23 \mathrm{ff}$.

${ }^{52}$ F. López Sanchéz, 'Le monnayage d'Olybrius ou l'affirmation de l'occident face a l'orient', Cahiers Numismatique 153 (2002) $31 \mathrm{ff}$.
} 